\title{
Ocular tropism of coronavirus (CoVs): a comparison of the interaction between the animal-to-human transmitted coronaviruses (SARS-CoV-1, SARS-CoV-2, MERS-CoV, CoV-229E, NL63, OC43, HKU1) and the eye
}

\author{
Eman Al-Sharif • Diego Strianese (1) - Nada H. AlMadhi • Antonella D'Aponte • \\ Roberto dell'Omo $\cdot$ Rita Di Benedetto $\cdot$ Ciro Costagliola
}

Received: 19 May 2020/Accepted: 29 August 2020/Published online: 3 September 2020

(C) Springer Nature B.V. 2020

\begin{abstract}
Purpose Several studies have reported conflicting results on ocular manifestations and transmission of coronavirus disease 2019 (COVID-19) whose causative virus, SARS-CoV-2, belongs to the coronavirus family, the seventh recognized as a human pathogen and the third causing a severe clinical syndrome. COVID-19 primarily affects the lungs, similar to the other human coronaviruses. Comparing the relation between the animal-to-human transmitted coronaviruses (SARS-CoV-1, SARS-Cov-2, MERS-CoV,
\end{abstract}

E. Al-Sharif · D. Strianese $(\bowtie)$.

N. H. AlMadhi · A. D'Aponte

King Khaled Eye Specialist Hospital, Riyadh, Kingdom of

Saudi Arabia

e-mail: strianes@unina.it

E. Al-Sharif

Department of Ophthalmology, College of Medicine, Princess Nourah Bint Abdulrahman University, Riyadh, Kingdom of Saudi Arabia

\section{Strianese}

Department of Neuroscience, Reproductive Sciences and Dentistry, University of Naples Federico II, 80121 Naples, Italy

R. dell'Omo - C. Costagliola

Department of Medicine and Health Sciences "V.

Tiberio", University of Molise, Campobasso, Italy

R. Di Benedetto

Department of Preventive Medicine, ASL Napoli 1

Centro, Naples, Italy
CoV-229E, NL63, OC43, HKU1) and the eye may contribute to determining their actual eye-tissue tropism and risk of ocular transmission.

Methods Literature review was conducted via Pubmed.gov, Google Scholar and medRixv using the following keywords: COVID-19, SARS-CoV-2, SARS-CoV-1, MERS-CoV, CoV-229E, NL63, OC43, HKU1, conjunctivitis, tear swab, ocular expression, ocular symptoms and human angiotensin converting enzyme- 2 expression. Studies with lack in methodology were excluded.

Results Sixteen observational studies were selected. The range for detection of viral RNA in tears was 0-8\% for SARS-CoV-1 and $0-5.3 \%$ for SARS-CoV2 , while no reports were found for other coronaviruses. Ocular manifestations have been reported for NL63 and SARS-CoV-2. Ocular symptoms in the form of conjunctivitis/conjunctival congestion predominantly were detected in $65(3.17 \%)$ out of 2048 reported patients with COVID-19 (range of 0.8-32\%). Eye symptoms were not reported for the other coronaviruses.

Conclusions Data aggregation for coronaviruses shows a relatively low eye-tissue tropism. Conjunctival congestion is an uncommon manifestation of COVID-19 similar to all human coronaviruses' infections. In a low percentage of patients, the virus can be excreted in ocular fluids at different stages of the infection, regardless of positive SARS-Cov-2 throat swab. Albeit high viral loads in ocular tissue seem to have relatively low prevalence, the eye should be 
regarded as a potential source of infection dissemination for COVID-19.

Keywords COVID-19 - Precautions - Eye · Conjunctivitis - SARS-CoV-2 - Ophthalmologists · Coronavirus

\section{Introduction}

The eye may serve as a site of virus replication and as a gateway for virus transferring to extraocular sites, for instance the respiratory system. This is achieved primarily by the nasolacrimal system, which provides an anatomical bridge between ocular and respiratory tissues. This anatomical conduct may cause drainage of immunizing agents to nasal tissue following topical ocular administration as well as the spread of intranasally administered solutions to the conjunctival mucosal surface. Linkage of the ocular mucosal immune system, which includes conjunctiva, cornea, lacrimal glands and lacrimal drainage system, with nasal cavity-associated lymphoid tissue in the nasolacrimal ducts, further supports the immunological interdependence between ocular and respiratory tract tissues. Ocular tropism of respiratory viruses has been extensively studied and reported [1].

The coronaviruses (CoVs) have become the major pathogens of emerging respiratory disease outbreaks in the last 20 years. They are a large family of singlestranded RNA viruses ( + ssRNA) that can be isolated from different animal species. Among coronaviruses which have circulated in the human population, two were identified in the 1960 s $(\mathrm{HCoV}-229 \mathrm{E}$ and $\mathrm{HCoV}$ OC43), and two others (HCoV-HKU1 and HCoVNL63) were identified recently [1]. SARS-associated coronavirus was first identified in 2003, whereas (MERS-CoV) was first identified in Saudi Arabia in 2012 [2, 3]. For reasons yet to be explained, these viruses can cross species' barriers and can cause, in humans, illness ranging from the common cold to the more severe diseases such as the Middle East respiratory syndrome (MERS) and the severe acute respiratory syndrome (SARS). The potential for these viruses to cause a pandemic worldwide seems to be a serious public health risk.

Coronavirus disease 2019, known as COVID-19, is an emerging infection which is caused by the severe acute respiratory syndrome coronavirus-2 (SARSCoV-2) that was first reported in Wuhan city, China, late in December 2019 [4]. Since then, the coronavirus outbreak has been spreading rapidly and extensively across continents and the number of infected cases and ensuing deaths is continuously rising worldwide. This led the World Health Organization (WHO) to proclaim it a global pandemic earlier in March 2020. Since the very beginning of this pandemic, warnings regarding an impending epidemic were raised up by a young ophthalmologist, Dr. Li Wenliang, who passed away because of infection by COVID-19 on February 7, 2020 [5]. Thereafter, several other ophthalmologists became ill in different parts of the world. This raised a lot of concerns among both ophthalmologists and patients. Thus, several studies have been published in the last weeks to better address the relation between SARS-CoV-2 and the eye. Given the relatively shortterm experience with this pandemic, data available are still too scarce to draw robust conclusions. Nevertheless, we thought it would be useful to conduct a qualitative systematic review of the literature focusing on the relation between the known epidemic zoonotic coronaviruses and the eye, examining the spectrum of ocular manifestations and routes of transmission, in the attempt to aid the understanding of the actual coronavirus-eye interaction.

\section{Methods}

Eligibility criteria

All types of published observational studies (case reports, case series and cross-sectional studies) published in the period between January 1, 2002, and April 30, 2020, and reporting ocular manifestations/ ocular transmission of coronaviruses-related infection were reviewed. Studies judged as having relevant flaws in methodology were excluded. Only studies published in the English language were considered.

Search methods for identifying studies

This was accomplished via PubMed, Google Scholar and medRixv e-databases, using and matching the following keywords: COVID-19, SARSCoV2, SARS, SARSCoV1, MERS, MERS-CoV, CoV-229E (alpha coronavirus), NL63 (alpha coronavirus), OC43 (beta 
coronavirus), HKU1 (beta coronavirus), eye symptoms, conjunctivitis, tear swab, ocular expression, ocular symptoms, ophthalmology and human angiotensin-converting enzyme 2 (ACE2) expression.

Study selection

A team of three reviewers (ES, DS and AD) searched the specified databases and reviewed all the eligible articles independently. All included articles were agreed upon by all researchers. Criteria for selection were as follows: homogeneity in the directions and degrees of results and retrospective observational studies with good reference standards.

Data collection, synthesis and analysis

The following information was derived from each of the included studies: study design, the total number of included patients, number of patients with ocular manifestations, number of patients undergoing PCR testing from conjunctival secretions or tears and number of patients undergoing laboratory confirmative tests of their coronavirus infection. One researcher completed data abstraction (ES) using a standardized abstraction form to collect the study results. We then summarized nonnumerically the key findings.

\section{Results}

Sixty-one papers were reviewed; of these, 16 studies reporting the ocular findings and conjunctival/tear swab PCR results of patients affected by coronaviruses were considered for analysis (Fig. 1). Among these, four studies (three case series and one longitudinal cross-sectional study) reported the relationship between the eye and SARS-CoV-1 (Table 1). Clinical ocular manifestations were absent in all SARS-CoV-1 patients, and viral RNA was detected in the conjunctival secretions and tears in three cases out of 120 $(2.5 \%)$ with a range of $0-8 \%$ [6-9].

Conversely, 12 observational studies (three case reports, three case series and six cross-sectional studies) reported the relationship between the eye and the emerging SARS-CoV-2 (Table 2) [10-21]. Overall, ocular symptoms, in the form of conjunctivitis/conjunctival congestion predominantly, were detected in 65 out of 2048 examined patients
$(3.17 \%)$ with a range of $0.8-32 \%$. In almost all cases, the diagnosis of COVID-19 was confirmed by nasopharyngeal swabs or other methods. A total of 414 patients underwent PCR testing of samples obtained from ocular fluids but the viral RNA was detected in 11 patients collectively, accounting for a rate of $2.7 \%$ (range of $0-5.3 \%$ ).

Liang and $\mathrm{Wu}[10]$ reported the presence of viral RNA in the conjunctival secretions of a patient diagnosed with severe COVID-19 using real-time polymerase chain reaction (RT-PCR) assay. Of note, this patient demonstrated no conjunctivitis clinically. The authors further hypothesized the proportionate association between the viral load and the severity of disease. In comparison, $\mathrm{Wu}$ and associates reported positive conjunctival reverse-transcriptase polymerase chain reaction results (RT-PCR) only in two out of 12 patients with ocular symptoms and positive SARS-CoV-2 nasopharyngeal swabs [11]. Similarly, a small study testing the conjunctival secretions and tears (collected twice over 2-3 days) of 30 confirmed COVID-19 patients demonstrated the presence of viral RNA (in both samples) in one patient only who also showed clinical signs of conjunctivitis [12]. In an attempt to study the possible ocular transmission of COVID-19, Zhou et al. retrospectively tested by PCR the conjunctival swabs of 67 patients with suspected $(n=4)$ or confirmed ( $n=63)$ COVID-19 and found that three confirmed cases with no ocular symptoms tested positive (one confirmed and two probable positive PCR assays). Though, the only patient presenting with symptoms of mild conjunctivitis, an anesthesiologist who acquired the infection from a confirmed COVID-19 patient during intubation, had negative conjunctival swab results [13].

A recent report from the National Institute for Infectious Diseases "Lazzaro Spallanzani" describes a 65-year-old woman, who traveled from Wuhan, China, to Italy in January 2020 and was admitted with respiratory symptoms after one week from her arrival. She presented with nonproductive cough, sore throat, coryza and bilateral conjunctivitis. Infection with SARS-CoV-2 was confirmed by performing RT-PCR assay on sputum samples. On day 3 after hospital admission, owing to the persistence of conjunctivitis, an ocular swab was collected and viral RNA was detected. Subsequent ocular samples collected with almost daily frequency were positive up to day 21 , with declining virus concentrations. Conjunctivitis 

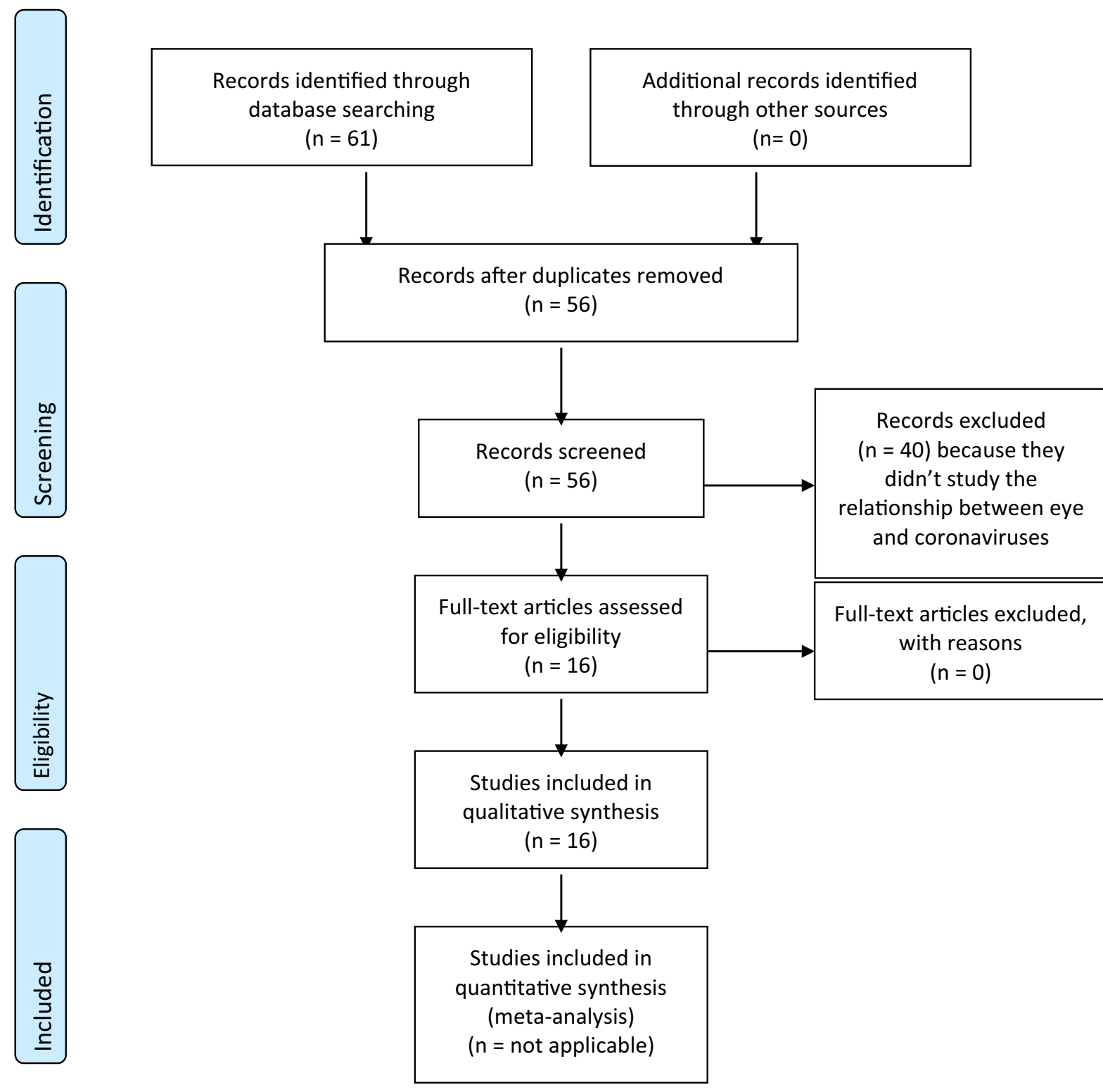

Fig. 1 Prisma flowchart for included studies

greatly improved at day 15 and apparently resolved at day 20. However, SARS-CoV-2 RNA was detected again at day 27 in conjunctival swabs after it was undetectable in nasal swabs [20]. On the other hand, Yu et al. [14] compared viral shedding in tears with the nasopharyngeal swabs' results of 17 patients during the course of COVID-19 infection. No evidence was found of SARS-CoV-2 shedding in tears through the course of the disease even when nasopharyngeal swabs' samples continued to show positive results.
Only one patient showed ocular symptoms during the disease course, but no evidence of SARS-CoV-2 could be found in this patient's tear samples.

In terms of ocular manifestations, a study published by $\mathrm{Wu}$ and colleagues on ocular findings in COVID-19 patients showed that approximately one-third of patients $(12 / 38,31.6 \%)$ had eye manifestations such as conjunctival redness, chemosis, tearing and increased secretions. Interestingly, the majority of these patients were considerably ill (four were 
Table 1 Summary of published studies reporting the association between SARS-CoV1 and the eye

\begin{tabular}{|c|c|c|c|c|c|}
\hline Author & $\begin{array}{l}\text { Publication } \\
\text { date }\end{array}$ & $\begin{array}{l}\text { Reported ocular } \\
\text { manifestations }\end{array}$ & $\begin{array}{l}\text { Laboratory- } \\
\text { confirmed SARS- } \\
\text { CoV1 }\end{array}$ & $\begin{array}{l}\text { Conjunctival swabs/secretions/tears PCR results if } \\
\text { available }\end{array}$ & $\begin{array}{l}\text { Quality of } \\
\text { evidence }\end{array}$ \\
\hline $\begin{array}{l}\text { Yuen } \\
\text { et al. } \\
{[9]}\end{array}$ & April 2005 & $n=0 / 45$ & - & - & $\begin{array}{l}4 \text { (prospective } \\
\text { case series) }\end{array}$ \\
\hline $\begin{array}{l}\text { Loon } \\
\text { et al. } \\
{[6]}\end{array}$ & July 2004 & $n=0 / 36$ & Yes $(n=8 / 36)$ & $\begin{array}{l}\text { Positive for three patients who had no symptoms, } \\
\text { one of the three had only positive tears PCR }\end{array}$ & 4 (case series) \\
\hline $\begin{array}{l}\text { Chan } \\
\text { et al. } \\
\text { [7] }\end{array}$ & July 2004 & $n=0 / 20$ & Yes $(n=5 / 20)$ & Negative for all 20 patients & $\begin{array}{l}4 \text { (prospective } \\
\text { case series) }\end{array}$ \\
\hline $\begin{array}{l}\text { Leong } \\
\text { et al. } \\
{[8]}\end{array}$ & $\begin{array}{l}\text { October } \\
2004\end{array}$ & $n=0 / 64$ & Yes $(n=5 / 64)$ & Negative for all patients & $\begin{array}{l}4 \text { (cross- } \\
\text { sectional } \\
\text { study) }\end{array}$ \\
\hline
\end{tabular}

considered as moderate, two severe and six critical based on PC-NCP guidelines). Among these patients, eye symptoms were the first sign of COVID-19 only in one patient $(2.5 \%)$. Almost all patients with eye findings (11 out of 12) had positive nasopharyngeal swabs, and two of these tested positive for COVID-19 by PCR of conjunctival swabs. This study also suggested that patients developing eye manifestations were more likely to have abnormal blood tests (white blood cell count, C-reactive protein, lactate dehydrogenase and prolactin) compared to patients without ocular symptoms. In spite of the limited sample size ( $n=38$ patients), this study is among the first to report a direct clinical relationship between the eye and COVID-19 [11]. Based on this study, it seems that the presence of ocular findings might be predictive of a more severe clinical course.

The incidence of conjunctival congestion was estimated to be less than $1 \%$ based on the report of WHO-China Joint Mission report on COVID-19 that studied 55,924 laboratory-confirmed cases [22]. Another study that comprehensively reviewed the clinical presentation of 1099 confirmed cases of COVID-19 showed that conjunctivitis is an uncommon presentation occurring in only $0.9 \%$ of the patients [15]. A recent study conducted by Chen and associates on 534 patients with COVID-19 (64\% positive by nasopharyngeal swab PCR) showed that 25 (4.68\%) patients had conjunctival congestion that lasted from 2 to 12 days (average duration: $4.9 \pm 2.6$ days). In fact, conjunctival congestion was the initial presenting manifestation in three of these patients. Other common reported manifestations were as follows: dry eye $(112,20.97 \%)$, blurred vision (68, $12.73 \%)$, foreign body sensation $(63,11.80 \%)$, tearing $(55,10.3 \%)$, itching $(53,9.9 \%)$, conjunctival secretions $(52,9.7 \%)$, ophthalmoplegia $(22,4.1 \%)$ and photophobia $(15,2.8 \%)$. Some of these ocular manifestations, such as dry eyes, blurred vision and foreign body sensation, were reported for the first time in this study. Notably, $60.11 \%$ (321) of these patients spent a considerable amount of their day, more than four hours, on short-distance reading and this could explain the high incidence of these dryness-related symptoms reported in this study. Bilateral lung infiltrates on CTscan were detected in $68 \%$ of the patients with conjunctival congestion, and this supports the assumption of possible correlation between disease severity and occurrence of ocular manifestations [18].

An NL63-related conjunctivitis was reported in two cases. The first case was a 7-month-old child with bronchitis and conjunctivitis [23]. The second case was associated with Kawasaki disease. However, it is unclear if conjunctivitis in HCoV-NL63-infected patients was due to the coronavirus itself or rather represented a manifestation of disease caused by an unrelated pathogen or disease [24].

Concerning the other coronaviruses, i.e., MERS$\mathrm{CoV}, 229 \mathrm{E}$ (alpha coronavirus), OC43 (beta coronavirus), HKU1 (beta coronavirus), we did not find any studies in the literature regarding ocular manifestations or conjunctival/tear swab PCR results. 
Table 2 Summary of published studies reporting ocular manifestations of COVID-19

\begin{tabular}{|c|c|c|c|c|c|}
\hline Author & $\begin{array}{l}\text { Publication } \\
\text { date }\end{array}$ & $\begin{array}{l}\text { Reported clinical ocular symptoms } \\
\text { and manifestations }\end{array}$ & $\begin{array}{l}\text { Laboratory- } \\
\text { confirmed COVID- } \\
19\end{array}$ & $\begin{array}{l}\text { Conjunctival swabs/ } \\
\text { secretions/tears PCR } \\
\text { results if available }\end{array}$ & $\begin{array}{l}\text { Quality of } \\
\text { evidence }\end{array}$ \\
\hline $\begin{array}{l}\text { Lu et al. } \\
\text { [17] }\end{array}$ & $\begin{array}{l}\text { February } 6, \\
2020\end{array}$ & $n=1$ patient with conjunctivitis & - & - & 5 (case report) \\
\hline $\begin{array}{l}\text { Zhou } \\
\text { et al. } \\
{[13]}\end{array}$ & $\begin{array}{l}\text { February } \\
12,2020\end{array}$ & $n=1 / 67$ patients had conjunctivitis & $\begin{array}{l}\text { Yes }(n=63 / 67 \\
\text { confirmed })\end{array}$ & $\begin{array}{l}\text { Confirmed positive for } \\
\text { one patient and probable } \\
\text { for two patients, all } \\
\text { without ocular } \\
\text { symptoms }\end{array}$ & $\begin{array}{l}4 \text { (retrospective } \\
\text { cohort study) }\end{array}$ \\
\hline $\begin{array}{l}\text { Xia et al. } \\
\text { [12] }\end{array}$ & $\begin{array}{l}\text { February } \\
26,2020\end{array}$ & $n=1 / 30$ patients had conjunctivitis & Yes & $\begin{array}{l}\text { Positive only for the one } \\
\text { patient who had } \\
\text { conjunctivitis }\end{array}$ & $\begin{array}{l}4 \text { (prospective } \\
\text { interventional } \\
\text { case series) }\end{array}$ \\
\hline $\begin{array}{l}\text { Sun et al. } \\
{[16]}\end{array}$ & $\begin{array}{l}\text { February } \\
26,2020\end{array}$ & $\begin{array}{l}n=2 / 102 \text { patients had } \\
\text { conjunctivitis }\end{array}$ & $\begin{array}{l}\text { Yes }(n=72 / 102 \\
\text { overall and } n=2 / \\
72 \text { patients with } \\
\text { eye symptoms) }\end{array}$ & $\begin{array}{l}\text { Positive only for the one } \\
\text { patient who had } \\
\text { conjunctivitis and } \\
\text { laboratory-confirmed } \\
\text { COVID-19 }\end{array}$ & $\begin{array}{l}4 \text { (cross- } \\
\text { sectional } \\
\text { study) }\end{array}$ \\
\hline $\begin{array}{l}\text { Guan } \\
\text { et al. } \\
\text { [15] }\end{array}$ & $\begin{array}{l}\text { February } \\
28,2020\end{array}$ & $\begin{array}{l}n=9 / 1099 \text { patients with } \\
\text { conjunctival congestion }\end{array}$ & Yes & - & $\begin{array}{l}4 \text { (cross- } \\
\text { sectional) }\end{array}$ \\
\hline $\begin{array}{l}\text { Chen } \\
\text { et al. } \\
{[18]}\end{array}$ & $\begin{array}{l}\text { March 16, } \\
2020\end{array}$ & $\begin{array}{l}n=25 / 534 \text { patients with } \\
\text { conjunctival congestion, } n=112 \\
\text { with dry eye, } n=68 \text { with blurred } \\
\text { vision, } n=68 \text { with foreign body } \\
\text { sensation, } n=22 \text { with } \\
\text { ophthalmoplegia, } n=52 \text { with } \\
\text { conjunctival secretions, } n=15 \\
\text { with photophobia, } n=55 \text { with } \\
\text { tearing and } n=53 \text { with itching }\end{array}$ & $\begin{array}{l}\text { Yes }(n=342 / 534 \\
\text { confirmed } \\
\text { positive and } \\
n=29 / 534 \\
\text { probable positive })\end{array}$ & - & $\begin{array}{l}4 \text { (cross- } \\
\text { sectional } \\
\text { study) }\end{array}$ \\
\hline $\begin{array}{l}\text { Liang } \\
\text { et al. } \\
{[10]}\end{array}$ & $\begin{array}{l}\text { March 18, } \\
2020\end{array}$ & $\begin{array}{l}n=3 / 37 \text { patients had conjunctival } \\
\text { congestion plus other } \\
\text { inflammatory signs }\end{array}$ & $\begin{array}{l}\text { Yes, for some } \\
\text { patients }\end{array}$ & $\begin{array}{l}\text { Positive for one patient } \\
\text { with severe COVID-19 } \\
\text { and no signs of } \\
\text { conjunctivitis }\end{array}$ & 4 (case series) \\
\hline $\begin{array}{l}\text { Yu et al. } \\
\text { [14] }\end{array}$ & $\begin{array}{l}\text { March 21, } \\
2020\end{array}$ & $\begin{array}{l}n=1 / 17 \text { patient had conjunctival } \\
\text { chemosis and injection during } \\
\text { hospital stay }\end{array}$ & Yes & $\begin{array}{l}\text { All } 64 \text { tear samples were } \\
\text { negative on viral culture } \\
\text { and PCR }\end{array}$ & $\begin{array}{l}4 \text { (prospective } \\
\text { study) }\end{array}$ \\
\hline $\begin{array}{l}\text { Wu et al. } \\
\text { [11] }\end{array}$ & $\begin{array}{l}\text { March 31, } \\
2020\end{array}$ & $\begin{array}{l}n=12 / 38 \text { patients had ocular } \\
\text { symptoms (conjunctival } \\
\text { congestion, epiphora, discharge) }\end{array}$ & $\begin{array}{l}\text { Yes }(n=28 / 38 \\
\text { overall and } \\
n=11 / 12 \\
\text { patients with eye } \\
\text { symptoms) }\end{array}$ & $\begin{array}{l}\text { Positive for two patients } \\
\text { with ocular symptoms } \\
\text { and positive } \\
\text { nasopharyngeal swab }\end{array}$ & 4 (case series) \\
\hline $\begin{array}{l}\text { Cheema } \\
\text { et al. } \\
{[21]}\end{array}$ & $\begin{array}{l}\text { April 2, } \\
2020\end{array}$ & $\begin{array}{l}n=1 \text { patient with } \\
\text { keratoconjunctivitis (red eye, } \\
\text { photophobia, watery discharge) }\end{array}$ & Yes & Weakly positive & 5 (case report) \\
\hline $\begin{array}{l}\text { Zhou } \\
\text { et al. } \\
{[19]}\end{array}$ & $\begin{array}{l}\text { April 17, } \\
2020\end{array}$ & $\begin{array}{l}n=8 / 121 \text { patients had ocular } \\
\text { symptoms (conjunctival redness, } \\
\text { discharge, tearing, itching, foreign } \\
\text { body sensation) }\end{array}$ & Yes & $\begin{array}{l}\text { Positive for three patients, } \\
\text { one of them only had } \\
\text { ocular symptoms }\end{array}$ & $\begin{array}{l}4 \text { (cross- } \\
\text { sectional } \\
\text { study) }\end{array}$ \\
\hline $\begin{array}{l}\text { Colavita } \\
\text { et al. } \\
\text { [20] }\end{array}$ & $\begin{array}{l}\text { April 17, } \\
2020\end{array}$ & $\begin{array}{l}n=1 \text { patient with bilateral } \\
\text { conjunctivitis }\end{array}$ & Yes & $\begin{array}{l}\text { Positive for multiple } \\
\text { specimens }\end{array}$ & 5 (case report) \\
\hline
\end{tabular}




\section{Discussion}

CoVs are positive-stranded RNA viruses with a crown-like appearance under an electron microscope (coronam is the Latin term for crown) due to the presence of spike glycoproteins on their envelope. The subfamily Orthocoronavirinae of the Coronaviridae family (order Nidovirales) classifies into four genera of CoVs: Alphacoronavirus (alphaCoV), Betacoronavirus (betaCoV), Deltacoronavirus (deltaCoV) and Gammacoronavirus (gammaCoV) [25]. Genomic characterization has shown that probably bats and rodents are the gene sources of alphaCoVs and betaCoVs. On the contrary, avian species seem to represent the gene sources of deltaCoVs and gammaCoVs [26, 27]. To date, seven human CoVs (HCoVs) have been identified as capable of causing respiratory, enteric, hepatic and neurological diseases in different animal species, including camels, cattle, cats and bats. Large studies report that $2 \%$ of the population are healthy carriers of a $\mathrm{CoV}$ and that these viruses are responsible for about $5-10 \%$ of acute respiratory infections [26, 27]. Common human CoVs listed by the Centers for Disease Control and Prevention (CDC) are 229E (alphaCoV); NL63 (alphaCoV); OC43 (betaCoV); and HKU1 (betaCoV) [23, 28-30]. They can cause common colds and self-limiting upper respiratory infections in immunocompetent individuals; however, in immunocompromised subjects, elderly and infants, lower severe respiratory tract infections are also reported. Conversely, the SARSCoV-1 (betaCoVs, B lineage), SARS-CoV-2 (betaCoVs, B lineage) and MERS-CoV (betaCoVs, C lineage) are the causative agents of large epidemic/pandemic outbreaks with variable clinical severity featuring respiratory and extra-respiratory manifestations [26, 27].

Interestingly, these latter viruses (SARS-CoV-1 and MERS-CoV) have probably originated from bats and then moved into other mammalian hosts, the Himalayan palm civet for SARS-CoV-1 and the dromedary camel for MERS-CoV, before jumping to humans $[31,32]$. The dynamics of SARS-CoV-2 are currently unknown, but there is speculation that it also has an animal origin. Some evidence, based on the results of viral genome sequencing, suggests that COVID-19 is transmitted to humans from bats which are likely to be the natural hosts of SARS-CoV-2; however, the potential amplifying mammalian host, intermediate between bats and humans, is not known. Since the mutation in the original strain could have directly triggered virulence towards humans, it is not certain that this intermediary exists [33].

At the cellular level, both SARS-CoV-1 and SARS$\mathrm{CoV}-2$ employ the human angiotensin-converting enzyme 2 (ACE2) as a surface receptor to gain access into the human cells and then subsequent viral replication ensue [26, 34]. These viruses attach to cells via their surface spike-like S-glycoprotein consisting of two subunits, $S 1$ and $S 2$, that are responsible for binding to the host cells' receptors and fusion with its membrane, respectively [33]. Cellular expression of ACE2 contributes to the viral cell-line tropism. Alveolar, bronchial and tracheal epithelial cells express ACE2; therefore, these viruses tend to disturb the respiratory system [27, 33]. In the eye, ACE2 is found mainly in the posterior segment (retina) and aqueous humor [35, 36]. Sun et al. had shown previously the weak binding capability of SARSCoV-1 to ACE2 expressed on the in vitro cultured conjunctival fibroblasts and epithelial cells as well as corneal epithelial cells [37]. These cellular receptors are also expressed in other organs such as the kidney, intestine, liver, intestinal tract, $\mathrm{T}$ lymphocytes and others. This might explain the wide range of manifestations accompanying these infections. Once the virus gains access into the host cells, it starts replicating to produce new virus particles that infect more cells. This infection triggers the innate immune system resulting in the release of inflammatory mediators and cytokines [33]. MERS-CoV utilizes a different receptor, dipeptidyl peptidase 4 (DPP4), also known as CD26, which is found predominantly in lung alveolar cells in addition to epithelial cells of various organs such as upper respiratory tract, kidney, small intestine and liver [38]. There are no reports of expression of CD26 at the eye level.

Reflecting on the ocular tropism of the well-known zoonotic coronaviruses might help us in understanding the behavior of the current SARS-CoV-2. Among the zoonotic coronaviruses that were studied intensively is the mouse hepatitis virus (MHV), strain JHM. This murine $\mathrm{CoV}$ is not only neurovirulent causing demyelinating disease, but it can also affect both anterior and posterior eye segments. This had led Robbins et al. in 1990 to inoculate this virus intravitreally in mice eyes to study its effect on retinal degeneration, and this animal model was later 
recognized as the experimental coronavirus retinopathy (ECOR). The authors observed mild anterior uveitis followed shortly by infection of almost all retinal layers with progressive retinopathy lasting 6-7 weeks post-infection [39]. Even when the virus was introduced by other routes into the eye, it still demonstrated retinotropism (neural retina and retinal pigment epithelium) [40]. The viral antigen was detected in the ganglion cells 10 days after inoculation, and degenerative changes continued up to 14 weeks after inoculation. These two studies demonstrate the biphasic nature of the disease which starts with an acute inflammatory phase and then a prolonged degenerative phase associated with retinal autoantibodies production [41]. Elevated levels of TNF-a and TNF receptors were observed in animal models, and this further supports the autoimmune reactivity during the second phase [42].

Recent data have shown that the ocular manifestations of SARS-CoV-2 in human beings are mild, which implicates low ocular tropism compared to the ECOR model. Nevertheless, the ocular immune responses observed in the ECOR model might carry some important therapeutic implications for SARSCoV-2. Based on animal models, Neri et al. speculated that this autoimmune response starts within 10-14 days of infection and this might represent a golden period to suppress the immune system by steroids or monoclonal agents preventing the subsequent cytokines storm and permanent multi-organ damage [43].

Despite that, the ACE-2 receptor, the main receptor for virus cellular entry uncovered so far, is present in a higher concentration in the posterior segment of the eye; yet, the vast majority of reported cases had anterior ocular manifestations, mostly conjunctivitis. This could be explained by the different binding ability of the virus to this receptor depending on the tissue type which expresses the receptor. Another explanation might be the low retinal tropism for this virus as SARS-Cov-2 can potentially access the posterior eye segment due to the resulting viremia, especially in immunocompromised patients; however, no evidence of retinal inflammation has been reported so far. Indeed, retinal inflammation in severely ill patients in the ICU might be also overlooked or poorly detected being due to their life-threatening condition. Performing retinal examinations on these patients would have been valuable to see if any changes were present. One more explanation could be the inability of the virus to induce a vigorous immune response even when it gains access to the posterior eye. Eventually, in months or years to come, we might expect some patients to develop an immune late response possibly characterized by destruction and fibrosis of neural cells, which might ultimately include the retinal layers, as already observed for some postinfective neurological conditions, such as canine distemper, the human subacute sclerosing panencephalitis and the encephalitis lethargica of Von Economo-whose relation with the 1918/1919 pandemic influenza is still under debate [44]

Eye as a route of transmission

The world is currently facing an outbreak crisis caused by SARS-CoV-2 which started more than 3 months ago. This infection primarily affects the respiratory system; however, the ocular involvement and ocular transmissibility of this infection are gaining more importance as this pandemic continues.

Recognizing the routes of transmission of SARSCoV-2 is of utmost importance to help mitigate its spread. The most important human-to-human route of transmission is through direct contact with viruscontaminated respiratory secretions (droplets and aerosols) [26]. Additionally, contact with virus-contaminated fomites, objects and environmental surfaces may result in transmission [45]. Whether or not the eye is a possible route of spread is still debatable. Nevertheless, evidence of possible ocular transmission is growing in the literature as the pandemic resumes universally. In this systematic review, the rate of SARS-CoV-2 viral shedding in tears and conjunctival secretions tested by PCR was $2.7 \%$. These results should be interpreted with caution as the time when samples were obtained from patients varied between the studies. Hypothetically, samples obtained late during the disease course might not yield positive results due to decreasing virus concentrations and seroconversion. Additionally, the viral load and severity of infection might affect the results.

Albeit the study includes a single patient, the report of the Spallanzani Institute with the SARS-CoV-2 traced in the tears from the onset until day 27 , after it has been tested negative for 5 days, has two relevant caveats: firstly, ocular involvement of SARS-CoV-2 may occur early in the COVID-19 course and 
secondly, the virus may continue to replicate in the conjunctival tissue even after the complete clinical recovery of the patient [20]. However, in other studies, patients with symptoms of upper respiratory tract infection did not demonstrate any viral shedding in tears, suggesting that the hypothesis of the lacrimal duct acting as a viral conduit may not be true and that transmission through tears regardless of the phase of infection is likely low $[10-14,16,20]$.

Indeed, studies evaluating the ocular secretions of SARS-CoV-1 patients during the outbreak had also conflicting results. Loon et al. from Singapore reported the detection of viral RNA in tear samples for three out of 33 patients using PCR early during the course of infection (within 9 days) [6, 46]. In contrast, Chan et al. reported the absence of SARS-CoV-1 RNA in tears and conjunctival scrapings obtained from 20 infected patients. The authors attributed this to decreased PCR sensitivity resulting in false-negative rates, and this can be lessened by repeated testing. Another proposed explanation is the presence of viral RNA in the tears for a short period only [7]. Similarly, Leong et al. reported no viral RNA in conjunctival swabs obtained from 64 SARS patients during the convalescent phase [8]. There are no reports on the presence of MERS-CoV RNA in tear samples or on ocular surface. This is consistent with the absence of the DPP4 in the upper respiratory tract and presumably on ocular surface too.

Since the conjunctiva is an exposed mucous membrane, theoretically, it is a possible portal of entry for the virus. Multiple studies emphasized the possibility of conjunctival contamination by respiratory droplets expelled by infected individuals. This may result in spreading the virus from the ocular surface mucous membrane through the tear nasolacrimal drainage system and down into the lower respiratory tract $[17,47]$. What further supports this notion is the transmission of COVID-19 to one of the national expert panel members inspecting Wuhan during the outbreak in whom conjunctivitis preceded the onset of pneumonia. He first experienced unilateral conjunctivitis, then respiratory symptoms and fever followed. This occurred in spite of adherence to precautionary measures except for eye protection, and this signifies the possibility of ocular transmission and importance of wearing protective goggles or face shields [17]. Moreover, a recent study evaluating the replication of SARS-CoV-2 and SARS-CoV-1 in ex vivo human conjunctival cells showed that both viruses demonstrated positive replication with SARSCoV-2 revealing more extensive infectivity than SARS-CoV-1 [48]. This again further emphasizes the eye being a potential entry site for the virus.

Despite the controversy of the currently available evidence, eye fluids should be regarded as a potential source of viral transmission until proven otherwise. In ophthalmology, physicians and other healthcare providers are in close contact with patients during ocular examination and drops instillation. This serves as a possible source of infection transmission from patients to physicians due to very close contact with ocular surface and secretions, particularly during slitlamp examination, direct and indirect ophthalmoscopy, contact intraocular pressure acquisition. In addition, physicians may also transmit the infection to other patients via direct contact and contaminated instruments if they do not adhere to infection control measures. Interestingly, an observational study showed that participants touched common surfaces and their mouth/nasal mucosa between 3.3-3.6 touches per hour [49].

Ocular and systemic clinical manifestations

COVID-19 has a wide clinical spectrum ranging from mild flu-like symptoms to severe pneumonia and acute respiratory distress syndrome. The case fatality rate seems to be $2.3 \%$ with death occurring mainly in the elderly and those with preexisting morbidities [50]. However, the actual casualty rate is not yet determined as having been reported with a wide geographical variation. Concerning SARS-CoV and MERS-CoV, the mortality rates are up to $10 \%$ and $35 \%$, respectively [51, 52].

The common presenting manifestations of COVID19 include fever, dry cough, shortness of breath and lung ground-like opacities on chest CT-scans [53-55]. The disease was further categorized by the Chinese CDC into mild, severe and critical disease based on the clinical presentation. The majority of patients $(81 \%)$ had mild disease (mild pneumonia to no pneumonia), whereas $14 \%$ suffered of severe disease manifesting with dyspnea, increased respiratory rate $(\geq 30 / \mathrm{min})$, decreased blood oxygen saturation $(\mathrm{SpO} 2 \leq 93 \%)$ and/or lung infiltrates ( $>50 \%$ within $1-2$ days). A minority of patients $(5 \%)$ were critically ill where they 
developed respiratory failure, septic shock and/or multiple organ failure [50].

The systemic presentation of SARS-CoV-1 and MERS-CoV is similar to COVID-19 except for the upper respiratory tract symptoms and gastrointestinal symptoms (ex: diarrhea) that are much less frequently seen with COVID-19 [45]. Eye symptoms have not been described previously with both SARS-CoV-1 and MERS-CoV [6-9, 56-59]. There were no ocular manifestations detected in 45 patients with acute SARS who were examined at baseline and then at twoand three-month follow-up [9]. No ophthalmological signs have been reported for the other CoVs, 229E (alpha coronavirus), OC43 (beta coronavirus), HKU1 (beta coronavirus), as well.

\section{Current precautionary measures in ophthalmology}

The number of infected healthcare workers is on the rise on a daily basis worldwide, with currently over 9000 healthcare workers infected by SARS-Cov-2 internationally with the highest rates being in China, Italy and recently the USA [60]. As healthcare workers are at the frontline in combating the COVID-19 outbreak, it is crucial to ensure their safety, not only to maintain continuous care, but also to prevent further transmission. Recommendations on precautionary measures to promote occupational safety and health were recently published by several international organizations such as the CDC and the WHO [61-64]. The standard universal precautions instructed to all healthcare facilities regardless of patients' infection statuses (suspected or confirmed) are as follows: limiting healthcare facilities crowding, safe hand hygiene practices, physical and social distancing, respiratory etiquette such as covering the mouth when coughing and the use of personal protective equipment (PPE) when dealing with suspected or infected patients [61].

As the world continues to investigate this emerging COVID-19 infection, lessons can be learned from our previous experience with SARS-CoV-1 and MERS$\mathrm{CoV}-1$ in the context of infection control and prevention as all diseases are highly contagious with presumably similar routes of transmission. In a previous case-control study conducted in China among healthcare providers who were taking care of SARS patients, all the 69 providers adhering to the four infection control measures (gown, gloves, mask and hand hygiene practices) did not contract the infection, while all the 13 infected staff omitted at least one of the four control measures [65]. Inadequate implementation of infection control measures was deemed to be an imperative risk factor for MERS-CoV infection among healthcare workers [66]. COVID-19 was classified as group B infectious disease by the recent guidelines of the China National Health Commission [67, 68]. However, they suggested that all healthcare workers should take protective measures "make no mistake approach" similar to group A infectious diseases (for example: plague and cholera) due to the current lack of evidence on this novel virus. These data necessitate an aggressive preparedness to hopefully mitigate the spread of SARS-CoV-2 among the healthcare community.

Many COVID-19 patients are asymptomatic on initial presentation, and one would likely present to ophthalmology clinics without respiratory symptoms or fever [17, 69-72]. Actually, reports published recently on the death of Dr. Li Wenliang claim that he mostly acquired the infection while treating his infected glaucoma patient who did not demonstrate any COVID-19 symptoms [17, 59]. Thus, all patients whether presenting to ophthalmic or nonophthalmic clinics should be questioned about any recent history of travel, exposure to infected or suspected individuals within the past 14 days. Ophthalmologists must be very vigilant when approaching a patient with a red eye because COVID-19 patients may present initially with conjunctivitis prior to the onset of respiratory symptoms [11]. Although $\mathrm{Wu}$ and his colleagues found only $5 \%$ positive conjunctival specimens in patients with SARS-Cov-2, it was still suggested to consider taking conjunctival swabs for RT-PCR when available to address whether SARS-CoV-2 is found in any patient who presents with conjunctivitis with no travel history or catarrhal symptoms. This could actually aid in early detection of subclinical cases and subsequent containment of the disease [73].

Ophthalmologists were alleged to be among the highest risk subspecialties susceptible to contract the infection due to the face-to-face proximity during slitlamp biomicroscopy examination, direct and indirect ophthalmoscopy which highly expose them to aerosolized particles [74]. Therefore, a disinfection protocol was advised in clinic settings to clean potentially contaminated surfaces like slit lamps, lenses and Goldman tonometer tips using $70 \%$ alcohol-based 
wipes that are effective against coronaviruses, unlike adenoviruses that are more resistant to these alcoholbased disinfectants [75].

Also, large breath shields mounted on slit lamps are being currently used in many ophthalmic institutes as rationally they might be beneficial in minimizing droplet exposure. Nevertheless, these barriers can also get contaminated if not properly sterilized between patients, and in the meantime, there is no scientific evidence supporting the definite use of these shields [76]. It was also advised by many organizations to carry out a focused sufficient examination on those with respiratory symptoms and fever but yet demand an urgent ophthalmic assessment while using protective equipment, goggles and mask to both the patient and examiner. Additionally, patients should be kindly instructed to refrain from speaking during examination to decrease the risk of exposure [61, 62]. Wan et al. also suggested temporarily replacing the use of direct ophthalmoscope with binocular indirect ophthalmoscope as the former has shorter working distance [73].

The American Academy of Ophthalmology has listed numerous precautionary measures that should be implemented in ophthalmic institutes, specifically in clinics, operating theater and emergency room [76]. They also advised using the following interim guidance for triaging patients seeking ophthalmic assessment based on the clinical situation:

- Postpone any nonurgent ophthalmic issues until this outbreak is under control

- Follow the standard precautions, including hand hygiene and eye/nose/mouth protection, when dealing with patients with urgent ophthalmic conditions but no symptoms suggestive of COVID-19

- Employ extra precautions for patients with urgent ophthalmic conditions and respiratory symptoms only such as goggles, face shield, gloves, surgical mask or N-95 mask if an aerosol-generating procedure will be performed, masking the patient, immediate attendance to the patient and disinfection of the room after the patient departs

- Treat patients with suspected or confirmed COVID-19 and concurrent urgent ophthalmic conditions in a hospital setting with firm compliance with the CDC and/or hospital precautionary guidelines for care of these patients
Along with curfew and travel restrictions mandated globally, nonurgent and elective ophthalmology clinic appointments and operations are being postponed, especially for elderly and patients with comorbidities who are at increased risk of severe disease $[63,74,76]$. The CDC also recommended delaying all elective ambulatory provider visits, rescheduling elective and nonurgent admissions and procedures. These recommendations are also consistent with the recommendations of the American Academy of Ophthalmology, the Royal College of Ophthalmologists, American College of Surgeons and many other organizations. If the patient were to have a clinic appointment, it is advisable to contact them before their appointments ahead of time to ask about TOCC (travel, occupation, cluster and contact), fever and respiratory symptoms. If a patient had any of the above-mentioned, the appointment should be postponed for at least 14 days if possible. A well-equipped special clinic with a separate waiting area is mandated if appointment is urgent [63]. Other measures advised by many medical societies include the following: limiting the number of patients' companions, noncontact temperature measurement before entering the health institute, spacing out patients' appointments to minimize clustering in the waiting hall and social distancing; these are all measures taken and advised by many health societies $[62,63,73,74]$. Telemedicine is also gaining popularity among the different medical specialties to minimize the risk of exposure for both patients and healthcare workers.

The European Society of Ophthalmic Plastic and Reconstructive surgery has also recommended deferring any nonurgent procedure that requires general anesthesia as this carries increased risk of microaerosol generation. Also, they recommended that all patients scheduled to undergo high-speed procedures (for example, orbital decompression with bone drilling) should undergo prior testing for SARS-CoV-2 whenever possible. Nasal procedures like nasopharyngeal swabbing and endoscopic dacryocystorhinostomy should also be avoided or performed under high protection measures because of direct exposure to respiratory tract droplets [77, 78]. When an urgent ophthalmic operation needs to be done, local anesthesia is preferable to avoid general anesthesia as much as possible, as endotracheal intubation might irritate the mucosa which may generate respiratory tract particles [77]. If general anesthesia is essential, it is advised to 
have a thorough multidisciplinary assessment by an anesthesiologist, internist and ophthalmologist.

In order to further minimize exposure among healthcare workers in ophthalmic institutes, some facilities are advocating assigning healthcare providers into smaller groups with different working hours' shifts and schedules. This certainly facilitates proper tracing and isolation among these smaller clusters in case asymptomatic infected individuals were detected $[64,74]$. When exposure to a suspected COVID-19 patient does occur, healthcare workers are instructed to report immediately to the infection control personnel and isolate themselves at home away from other family members while monitoring themselves for any symptoms. A PCR test is usually performed as well [62].

\section{Conclusion}

Overall, conjunctivitis/conjunctival congestion is an uncommon manifestation of COVID-19 as well as for other coronaviruses' infections that showed a low eyetissue tropism. Although ocular transmission remains enigmatic, the most up-to-date evidence proved that the virus might be excreted in tears and conjunctival secretions and also replicate in conjunctival tissue up to 27 days after the onset of the disease; hence, the eye should be regarded as a potential source of infection dissemination. Until further evidence becomes available on ocular tissue tropism and permissiveness to the coronaviruses, ophthalmologists and ophthalmic-care providers must heighten their precautionary measures given that ophthalmic examinations and procedures necessitate close contact with patients.

\section{Acknowledgements None.}

Funding None.

\section{Compliance with ethical standards}

Conflicts of interest All authors of this study have no conflict of interest to disclose.

\section{References}

1. Belser JA, Rota PA, Tumpey TM (2013) Ocular tropism of respiratory viruses. Microbiol Mol Biol Rev 77:144-156
2. Peiris JSM (2003) The severe acute respiratory syndrome. N Engl J Med 349:2431-2441

3. Zaki AM, van Boheemen S, Bestebroer TM et al (2012) Isolation of a novel coronavirus from a man with pneumonia in Saudi Arabia. N Engl J Med 367:1814-1820

4. Zhou P, Yang X-L, Wang X-G et al (2020) A pneumonia outbreak associated with a new coronavirus of probable bat origin. Nature 579:270-273

5. Parrish RK, Stewart MW, Duncan Powers SL (2020) ophthalmologists are more than eye doctors-in memoriam $\mathrm{Li}$ Wenliang. Am J Ophthalmol 213:A1-A2

6. Loon S-C (2004) The severe acute respiratory syndrome coronavirus in tears. Br J Ophthalmol 88:861-863

7. Chan WM (2004) Tears and conjunctival scrapings for coronavirus in patients with SARS. Br J Ophthalmol 88:968-969

8. Leong HN, Chan KP, Khan AS et al (2004) Virus-specific RNA and antibody from convalescent-phase SARS patients discharged from hospital. Emerg Infect Dis 10:1745-1750

9. Yuen KSC, Chan W-M, Fan DSP et al (2004) Ocular screening in severe acute respiratory syndrome. Am J Ophthalmol 137:773-774

10. Liang L, Wu P (2020) There may be virus in conjunctival secretion of patients with COVID-19. Acta Ophthalmol. https://doi.org/10.1111/aos.14413 Epub ahead of print 18 March 2020

11. Wu P, Duan F, Luo C et al (2020) Characteristics of ocular findings of patients with coronavirus disease 2019 (COVID19) in Hubei Province, China. JAMA Ophthalmol. https:// doi.org/10.1001/jamaophthalmol.2020.1291 Epub ahead of print 31 March 2020

12. Xia J, Tong J, Liu M et al (2020) Evaluation of coronavirus in tears and conjunctival secretions of patients with SARSCoV-2 infection. J Med Virol 92:589-594 jmv.25725

13. Zhou Y, Zeng Y, Tong Y et al (2020) Ophthalmologic evidence against the interpersonal transmission of 2019 novel coronavirus through conjunctiva. Preprint, Ophthalmology. Epub ahead of print 12 February 2020. https://doi. org/10.1101/2020.02.11.20021956

14. Yu Jun IS, Anderson DE, Zheng Kang AE et al (2020) Assessing viral shedding and infectivity of tears in coronavirus disease 2019 (COVID-19) patients. Ophthalmology S0161642020303110

15. Guan W, Ni Z, Hu Y et al (2020) Clinical characteristics of coronavirus disease 2019 in China. N Engl J Med 382:1708-1720

16. Sun X, Zhang X, Chen X et al (2020) The infection evidence of SARS-COV-2 in ocular surface: a single-center crosssectional study. Preprint, Public and Global Health. Epub ahead of print 26 February 2020. https://doi.org/10.1101/ 2020.02.26.20027938

17. Lu C, Liu X, Jia Z (2020) 2019-nCoV transmission through the ocular surface must not be ignored. Lancet 395:e39

18. Chen L, Deng C, Chen X et al (2020) Ocular manifestations and clinical characteristics of 534 cases of COVID-19 in China: A cross-sectional study. Preprint, Ophthalmology. Epub ahead of print 16 March 2020. https://doi.org/10.1101/ 2020.03.12.20034678

19. Zhou Y, Duan C, Zeng Y et al (2020) Ocular findings and proportion with conjunctival SARS-COV-2 in COVID-19 patients. Ophthalmology 127:982-983 
20. Colavita F, Lapa D, Carletti F et al (2020) SARS-CoV-2 isolation from ocular secretions of a patient with COVID-19 in Italy with prolonged viral RNA detection. Ann Intern Med. https://doi.org/10.7326/M20-1176

21. Cheema M, Aghazadeh H, Nazarali S et al (2020) Keratoconjunctivitis as the initial medical presentation of the novel coronavirus disease 2019 (COVID-19). Can J Ophthalmol, S0008418220303057

22. WHO. WHO announces COVID-19 outbreak a pandemic. 3 November 2020

23. van der Hoek L, Pyrc K, Jebbink MF et al (2004) Identification of a new human coronavirus. Nat Med 10:368-373

24. Esper F, Shapiro ED, Weibel C et al (2005) Association between a novel human coronavirus and kawasaki disease. J Infect Dis 191:499-502

25. Cascella M, Rajnik M, Cuomo A et al (2020) Features, evaluation and treatment coronavirus (COVID-19). https:// www.ncbi.nlm.nih.gov/books/NBK554776/

26. Fung TS, Liu DX (2019) Human coronavirus: host-pathogen interaction. Annu Rev Microbiol 73:529-557

27. Yin Y, Wunderink RG (2018) MERS, SARS and other coronaviruses as causes of pneumonia: MERS SARS and coronaviruses. Respirology 23:130-137

28. CDC. Human Coronavirus Types. February 15, 2020, https://www.cdc.gov/coronavirus/types.html

29. Woo PCY, Lau SKP, Chu C-M et al (2005) Characterization and complete genome sequence of a novel coronavirus, coronavirus HKU1, from patients with pneumonia. J Virol 79:884-895

30. van der Hoek L (2007) (2007) Human coronaviruses: what do they cause? Antivir Ther 12(4B):651-658

31. Ithete NL, Stoffberg S, Corman VM et al (2013) Close relative of human middle east respiratory syndrome coronavirus in Bat South Africa. Emerg Infect Dis 19:1697-1699

32. Wang L-F, Eaton BT (2007) Bats, civets and the emergence of SARS. In: Childs JE, Mackenzie JS, Richt JA (eds) Wildlife and emerging zoonotic diseases: the biology, circumstances and consequences of cross-species transmission. Springer, Berlin, pp 325-344

33. Guo Y-R, Cao Q-D, Hong Z-S et al (2020) The origin, transmission and clinical therapies on coronavirus disease 2019 (COVID-19) outbreak-an update on the status. Military Med Res 7:11

34. Li W, Moore MJ, Vasilieva N et al (2003) Angiotensinconverting enzyme 2 is a functional receptor for the SARS coronavirus. Nature 426:450-454

35. Holappa M (2015) Ocular renin-angiotensin system with special reference in the anterior part of the eye. WJO 5:110

36. Senanayake PD, Drazba J, Shadrach K et al (2007) Angiotensin II and its receptor subtypes in the human retina. Invest Ophthalmol Vis Sci 48:3301

37. Sun Y, Liu L, Pan X, Jing M (2006) Mechanism of the action between the SARS-CoV S240 protein and the ACE2 receptor in eyes. Int Ophthalmol 6:783-786

38. Meyerholz DK, Lambertz AM, McCray PB (2016) Dipeptidyl peptidase 4 distribution in the human respiratory tract. Am J Pathol 186:78-86

39. Robbins SG, Detrick B, Hooks JJ (1990) Retinopathy following intravitreal injection of mice with MHV strain JHM. Adv Exp Med Biol 276:519-524
40. Robbins SG, Derrick B (1991) Ocular tropisms of murine coronavirus (strain JHM) after inoculation by various routes. Investig Ophthamol Vis Sci 32:1883-1893

41. Hooks JJ, Percopo C, Wang Y et al (1993) Retina and retinal pigment epithelial cell autoantibodies are produced during murine coronavirus retinopathy. J Immunol 151:3381

42. Hooper LC, Chin MS, Detrick B et al (2005) Retinal degeneration in experimental coronavirus retinopathy (ECOR) is associated with increased TNF- $\alpha$, soluble TNFR2 and altered TNF- $\alpha$ signaling. J Neuroimmunol 166:65-74

43. Neri P, Pichi F (2020) COVID-19 and the eye immunity: lesson learned from the past and possible new therapeutic insights. Int Ophthalmol 40:1057-1060

44. Maurizi CP (2010) Influenza caused epidemic encephalitis (encephalitis lethargica): the circumstantial evidence and a challenge to the nonbelievers. Med Hypotheses 74(5):798-801. https://doi.org/10.1016/j.mehy.2009.12. 012

45. Sun C, Wang Y, Liu G, et al (2020) Role of the Eye in Transmitting Human Coronavirus: What We Know and What We Do Not Know. Preprint, Medicine and Pharmacology. Epub ahead of print 17 March 2020. https://doi.org/ 10.20944/preprints202003.0271.v1

46. Loon SC, Lun K (2013) SARS: a timely reminder. Br J Ophthalmol 97:1217-1218

47. Qing H, Li Z, Yang Z et al (2020) The possibility of COVID-19 transmission from eye to nose. Acta Ophthalmol. https://doi.org/10.1111/aos.14412 Epub ahead of print 18 March 2020

48. Hui KPY, Cheung M-C, Perera RAPM et al (2020) Tropism, replication competence, and innate immune responses of the coronavirus SARS-CoV-2 in human respiratory tract and conjunctiva: an analysis in ex-vivo and in-vitro cultures. Lancet Respir Med S2213260020301934

49. Alonso WJ, Nascimento FC, Shapiro J et al (2013) Facing ubiquitous viruses: when hand washing is not enough. Clin Infect Dis 56:617-617

50. Wu Z, McGoogan JM (2019) Characteristics of and important lessons from the coronavirus disease 2019 (COVID-19) outbreak in china: summary of a report of 72 314 cases from the chinese center for disease control and prevention. JAMA. https://doi.org/10.1001/jama.2020.2648 Epub ahead of print 24 February 2020

51. CDC. In the absence of SARS-CoV transmission worldwide: guidance for surveillance, clinical and laboratory evaluation, and reporting, https://www.cdc.gov/sars/ surveillance/absence.html (2005)

52. Arabi YM, Arifi AA, Balkhy HH et al (2014) Clinical course and outcomes of critically ill patients with middle east respiratory syndrome coronavirus infection. Ann Intern Med 160:389-397

53. Wang D, Hu B, Hu C et al (2020) Clinical characteristics of 138 hospitalized patients with 2019 novel coronavirus-infected pneumonia in Wuhan China. JAMA 323:1061

54. Huang C, Wang Y, Li X et al (2020) Clinical features of patients infected with 2019 novel coronavirus in Wuhan. China The Lancet 395:497-506

55. Jiang F, Deng L, Zhang L et al (2020) Review of the clinical characteristics of coronavirus disease 2019 (COVID-19). 
J Gen Intern Med. https://doi.org/10.1007/s11606-02005762-w Epub ahead of print 4 March 2020

56. Ajlan AM, Ahyad RA, Jamjoom LG et al (2014) Middle east respiratory syndrome coronavirus (MERS-CoV) infection: chest CT findings. Am J Roentgenol 203:782-787

57. Alfaraj SH, Al-Tawfiq JA, Altuwaijri TA et al (2019) Middle east respiratory syndrome coronavirus in pediatrics: a report of seven cases from Saudi Arabia. Front Med 13:126-130

58. Cunha CB, Opal SM (2014) Middle east respiratory syndrome (MERS): a new zoonotic viral pneumonia. Virulence 5:650-654

59. Li JPO, Lam DSC, Chen Y et al (2020) Novel Coronavirus disease 2019 (COVID-19): the importance of recognising possible early ocular manifestation and using protective eyewear. Br J Ophthalmol 104:297-298

60. Lancet T (2020) COVID-19: protecting health-care workers. Lancet 395:922

61. CDC. Coronavirus disease 2019 (COVID-19), https://www. cdc.gov/coronavirus/2019-ncov/hcp/index.html

62. WHO. Coronavirus disease (COVID-19) outbreak: rights, roles and responsibilities of health workers, including key considerations for occupational safety and health, https:// www.who.int/publications-detail/coronavirus-disease(covid-19)-outbreak-rights-roles-and-responsibilities-ofhealth-workers-including-key-considerations-foroccupational-safety-and-health (18 Mar 2020)

63. Lai THT, Tang EWH, Chau SKY et al (2020) Stepping up infection control measures in ophthalmology during the novel coronavirus outbreak: an experience from Hong Kong. Graefes Arch Clin Exp Ophthalmol. https://doi.org/ 10.1007/s00417-020-04641-8 Epub ahead of print 3 March 2020

64. Michael Burdon. The Royal College of Ophthalmologists Protecting Patients, Protecting Staff. The Royal College of Ophthalmologists, 30 March 2020

65. Seto W, Tsang D, Yung R et al (2003) Effectiveness of precautions against droplets and contact in prevention of nosocomial transmission of severe acute respiratory syndrome (SARS). Lancet 361:1519-1520

66. Suwantarat N, Apisarnthanarak A (2015) Risks to healthcare workers with emerging diseases: lessons from MERSCoV, Ebola, SARS, and avian flu. Curr Opin Infect Dis 28:349-361

67. China National Health Commission. Announcement of national health commission of the people's republic of China. http://wwwnhcgovcn/jkj/s7916/202001/44a3 b8245e8049d2837a4f27529cd386shtml. Accessed 20 Jan 2020
68. Chang D, Xu H, Rebaza A et al (2020) Protecting healthcare workers from subclinical coronavirus infection. Lancet Respir Med 8:e13

69. Luo S-H, Liu W, Liu Z-J et al (2020) A confirmed asymptomatic carrier of 2019 novel coronavirus (SARS-CoV-2). Chin Med J 133:1123-1125

70. WHO (2020) Report of the WHO-China Joint Mission on coronavirus disease 2019 (COVID-19). https://www.who. int/docs/default-source/coronaviruse/who-china-jointmission-on-covid-19-final-report.pdf

71. Day M (2020) Covid-19: identifying and isolating asymptomatic people helped eliminate virus in Italian village. BMJ

72. Bai Y, Yao L, Wei T et al (2020) Presumed asymptomatic carrier transmission of COVID-19. JAMA. https://doi.org/ 10.1001/jama.2020.2565 Epub ahead of print 21 February 2020

73. dell'Omo R, Filippelli M, Semeraro F et al (2020) Effects of the first month of lockdown for COVID-19 in Italy: a preliminary analysis on the eyecare system from six centers. Eur J Ophthalmol. https://doi.org/10.1177/ 1120672120953074

74. Lanni V, Iuliano A, Laezza MP et al (2020) Oculoplastic management of patients in the Covid-19 era: experience from an Italian tertiary referral center. Orbit 39(5):391-393. https://doi.org/10.1080/01676830.2020.1775264

75. Rabenau HF, Kampf G, Cinatl J et al (2005) Efficacy of various disinfectants against SARS coronavirus. J Hosp Infect 61:107-111

76. Chodosh J, Holland G, Yeh S (2020) Important coronavirus updates for ophthalmologists. American Academy of Ophthalmology (AAO), https://www.aao.org/headline/alertimportant-coronavirus-context

77. Tran K, Cimon K, Severn M et al (2012) Aerosol generating procedures and risk of transmission of acute respiratory infections to healthcare workers: a systematic review. PLoS ONE 7:e35797

78. European Society of Ophthalmic Plastic and Reconstructive Surgery. Recommendations for oculoplastic surgeons during the COVID-19 pandemic, https://www.esoprs.eu/news/ recommendations-for-oculoplastic-surgeons-during-thecovid-19-pandemic/. Accessed 22 Mar 2020

Publisher's Note Springer Nature remains neutral with regard to jurisdictional claims in published maps and institutional affiliations. 